\title{
The Effect of Health Promotion of Animation Videos on Behavior of Prevention of Dengue Hemorrhagic Fever in the Work Area of Health Center, Pasar Minggu District, South Jakarta City in 2021
}

\author{
Aisyiah $^{1 *}$,Tommy J. Wowor ${ }^{2}$, Yakobus Ahufruan ${ }^{3}$ \\ 1,2,3Nursing Department, National University of Jakarta, Indonesia; Aisyiah@civitas.unas.ac.id (Corresponding Author)
}

\begin{tabular}{ll}
\hline Article Info: & ABSTRACT \\
\cline { 2 - 2 } Submitted: & Dengue hemorrhagic fever (DHF) is one of the main causes of morbidity and mortality \\
29-07-2021 & in the community. One of the efforts made in the context of preventing DHF is through \\
Revised: & various health promotions by providing information and communication such as \\
$12-10-2021$ & counseling and campaigns, electronic media, print media, and so on to increase \\
Accepted: & knowledge, attitudes, and practices in the community so that people have awareness \\
$12-10-2021$ & in changing and improving their health status. . This study aims to determine the effect \\
& of health promotion through animated videos on knowledge, attitudes, and practices \\
towards dengue prevention in the work area of the Pasar Minggu Subdistrict Health & Center. The sample of this study was 56 families and sampling was carried out using \\
DOI: & the purposive sampling technique. The results showed that there was an increase in \\
https://doi.org/10.53713/nhs.v1i2.25 & knowledge, attitudes, and also the practice of preventive measures against dengue \\
& fever in the community after being given health promotion in the form of animated \\
& videos ( $p$-value < 0.05). Therefore, the importance of health promotion media in \\
& changing a person's knowledge, attitudes, and behavior or actions so that they can \\
undergo better health behaviors.
\end{tabular}

This work is licensed under CC BY-SA License.
Keywords: knowledge; attitude; practice; health promotion; dengue hemorrhagic fever

\section{INTRODUCTION}

Dengue Hemorrhagic Fever (DHF) is one of the environmental-based infectious diseases, which is still a big problem in society. Dengue hemorrhagic fever is also one of the main causes of morbidity and mortality in the community. Dengue hemorrhagic fever is a disease caused by dengue virus infection and is an acute disease with clinical manifestations of bleeding that causes shock that leads to death (Hasyim, 2013). According to the World Health Organization (WHO) (2020), DHF is a disease caused by a mosquito-borne virus that has spread rapidly in all countries in recent years. Dengue virus is a single-stranded RNA virus surrounded by a core protein (core protein or C-protein) forming a viral nucleus that covers a double lipid layer containing structural membrane proteins and forms the envelope of viral particles. This virus belongs to the type flavivirus, Flaviviridae family, also known as DENV which consists of four serotypes namely DENV-1, DENV-2, DENV-3, DENV-4. Fourth serotypes in the know can cause human disease with a wide spectrum of symptoms and DENV virions diameter measuring about $65 \mathrm{~nm}$ while measuring viral core $30 \mathrm{~nm}$ (Guzman, et al, 2016). Virus dengue is transmitted by female mosquitoes of the species mainly Aedes Egyptian, at the level of lower, Ae. Albopictus and both types of mosquitoes can generally be found in areas that are considered endemic areas. Another study on the prevalence of dengue fever estimates that 3.9 billion people are at risk of infection with the dengue virus, although there is a risk of infection in 129 countries. There is $70 \%$ of the actual burden in Asia and the number of dengue cases reported to WHO has increased more than 8-fold over the last two decades, from 505,430 cases in 2000 to more than 2.4 million in 2010, and 4.2 million. in 2019. Deaths reported between 2000 and 2015 increased from 960 to 4032 . Dengue continues to affect several countries, with reports of increasing cases in Bangladesh, Brazil, Cook Islands, Ecuador, India, Indonesia, Maldives, Mauritania, Mayotte, Nepal, Singapore, Sri Lanka, Sudan, Thailand, Timor-Leste, and Yemen (WHO, 2020).

According to data from the South Jakarta Health Sub-department, the number of dengue fever cases in the South Jakarta area has increased from 2017 to 642 cases when compared to 755 cases of dengue fever in 2018, the incident rate $(\mathrm{IR})$ of DHF cases per sub-district in the Jakarta area. South 2018 based on reports from Puskesmas in South Jakarta, Mampang Prapatan Health Center, IR 19.3, Kebayoran Lama Health Center IR, 27.3, Tebet Health Center IR, 32.3, Pancoran Health Center IR, 32.7, Pesanggar Health Center IR, 33.6, Kebayoran Baru Health Center IR, 37.1, 
Setiabudi Public Health Center IR, 39.8, Pasar Minggu Health Center IR, 48.2, while in 2020 DKI Jakarta occupies the fourth position out of ten provinces which are the areas with the most dengue fever cases, with a total of 4,277 cases IR with 56.04, per 100,000 population, evaluation DHF in South Jakarta 42nd week of 2020 which was given by the Head of the Health Promotion Program at Pasar Minggu District Health Center that in the month of January to September 2020 cumulative DHF data from DKI Jakarta, for South Jakarta, both cumulative DHF and IR cases were ranked 3rd after East Jakarta and West Jakarta, while the lowest case was the Thousand Islands (Sudinkes, 2020). A referral health center located in the administrative area of South Jakarta City with a total IR of $48.2 \%$ in 2018 with a total of 84 cases in all Pasar Minggu Districts.

One of the efforts made in the context of preventing DHF is through various health promotions by providing information and communication such as counseling and campaigns, electronic media, print media, and so on to increase knowledge, attitudes, and practices in the community so that people have awareness in changing and improving their health status. Knowledge, attitudes, and behavior are interrelated so that when one of them is not good even though the other is good it has no meaning (Notoatmodjo, 2012). Health promotion is an effort or activity to create community behavior that is conducive to health. The term health promotion was formerly known as health education where the main goal was to provide education to the community to increase not only the level of public awareness or knowledge about health but more importantly to achieve good health behavior (Notoatmodjo, 2012).

There are several types of information media that can be used in health education or health promotion. In addition to lectures which are the most commonly used way to share knowledge and health facts, there are also health promotion media in the form of animated videos. Video is expected to increase the knowledge, attitudes, and behavior of the community in the context of preventing DHF (Mubarak, 2007). The results of research conducted by Pratiwi (2016) on "Providing Health Promotion with Lecture Methods and Video Animation", found a significant difference between lecture methods ( $p=0.02$ ) and animated videos $(p=0.000)$. RT 011/RW 004 Kampung Pisangan Poncol which is located in the Raguanan Village, Pasar Minggu Subdistrict, South Jakarta City, there are 125 families (KK) with dense settlements and adjacent to Poncol lake. This area often floods during the rainy season or heavy rain intensity In addition, RT 011 is in a low-lying position and often enters the rainy season, there are lots of puddles caused by conditions drainage which are often covered with garbage so that it is difficult for water to flow into the lake. Based on the description above, the researcher is interested in conducting further research on "The Effect of Health Promotion Video Animation on Prevention of Dengue Hemorrhagic Fever in the Work Area of the Puskesmas Kecamatan Pasar Minggu, South Jakarta City".

\section{METHOD}

This study used a quasi-experimental with no control group. The aim of this study is to determine the knowledge, attitudes, and practices of the community towards the prevention behavior of Dengue Hemorrhagic Fever. The study was conducted in 2021 in which respondents were given health promotion through the video method for 3 weeks. The knowledge, attitudes, and practices of the community on the prevention of dengue hemorrhagic fever were assessed through a questionnaire for pre and post intervention. The research population was 125 families in RT 011 Kampung Pisangan Poncol in the working area of Puskesmas Pasar Minggu, South Jakarta City. Sampling was carried out using a random sampling technique, namely purposive sampling where the technique of determining the sample with certain considerations was made by the researcher himself (Sugiyono, 2017). The sample size in this study used the Solvin formula so that a total sample of 56 families was obtained in RT/.011/04 Kampungan Pisangan Poncol, Ragunan Village in the working area of the Puskesmas Pasar Minggu, South Jakarta City. Data analysis used descriptive analysis for univariate and Wilcoxon on bivariate.

\section{RESULT}

Table 1. Frequency Distribution of Respondents by Knowledge Level

\begin{tabular}{ccccc}
\hline Knowledge & Mean & Standard Deviation & Minimum & Maximum \\
\hline Pre-test & 6.84 & 3.132 & 0 & 13 \\
\hline Post-test & 9.11 & 1.186 & 6 & 13 \\
\hline
\end{tabular}

Based on Table 1 shows that the average value of the level of knowledge of prevention dengue hemorrhagic fever before giving health promotion through the video method was 6.84 with the lowest score of 0 and the highest score 
of 13. While the average value of the level of knowledge after being given intervention through health promotion videos was 9.11 with a minimum score of 6 and a maximum of 13 . This shows that after being given health promotion through the video method, they have increased knowledge about the prevention of dengue hemorrhagic fever.

Table 2. Frequency Distribution of Respondents by Attitude

\begin{tabular}{ccccc}
\hline Attitude & Mean & Standard Deviation & Minimum & Maximum \\
\hline Pre-test & 49.61 & 6580 & 35 & 61 \\
\hline Post-test & 59.14 & 7.681 & 39 & 64 \\
\hline
\end{tabular}

Based on Table 2 shows that the average value of the attitude towards disease prevention dengue hemorrhagic fever before giving health promotion through the video method was 49.61 with the lowest score of 35 and the highest score of 61 . While the average value of attitudes after being given intervention through health promotion videos was 59.14 with a minimum score of 39 and a maximum of 64 . showed that after being given health promotion through the video method, there were differences in attitudes before and after being given a health promotion intervention with the video method about the attitude of preventing dengue hemorrhagic fever.

Table 3. Frequency Distribution of Respondents Based Prevention Practices

\begin{tabular}{ccccc}
\hline Practice & Mean & Standard Deviation & Minimum & Maximum \\
\hline Pre-test & 8.38 & 3.200 & 2 & 12 \\
\hline Post-test & 11.05 & 1.182 & 7 & 12 \\
\hline
\end{tabular}

Based on Table 3 shows that the average value of disease prevention practices fever dengue hemorrhagic fever before giving health promotion through the video method was 8.38 with the lowest score of 2 and the highest score of 12. While the average value of practice after being given an intervention through a health promotion video was 11.05 with a minimum score of 7 and a maximum of 12. This shows that after being given health promotion through the video method, there is an increase in practices regarding the prevention of dengue hemorrhagic fever.

Table 4. Effect of Health Promotion on Prevention of Dengue Hemorrhagic Fever (DHF) in South Jakarta

\begin{tabular}{llcccccc}
\hline \multicolumn{2}{c}{ Behavior } & Mean & $\begin{array}{c}\text { Negative } \\
\text { ranks }\end{array}$ & $\begin{array}{c}\text { Positive } \\
\text { ranks }\end{array}$ & Ties & Z-score & p-value \\
\hline Knowledge & Before & 23.46 & 6 & 39 & 11 & -4.506 & 0.000 \\
& After & 20.00 & & & & & \\
\hline Attitude & Before & 29.76 & 7 & 47 & 2 & -5.653 & 0.000 \\
& After & 12.36 & & & & & \\
\hline Practice & Before & 26.93 & 10 & 35 & 11 & -4.811 & 0.000 \\
& After & 9.25 & & & & & \\
\hline
\end{tabular}

Based on Table 4, the results of the analysis show that the average knowledge before being given intervention is 23.46 and after being given intervention is 20.00 , Attitudes before being given intervention is 29.76 and after being given intervention is 12.36, Practice before being given intervention is 26.93 and after the intervention was given 9.25. test results Wilcoxon obtained $\mathrm{P}$ value $(0.000)<(0.05)$ then $\mathrm{Ho}$ is rejected, meaning that there is an effect of health promotion on the prevention of dengue hemorrhagic fever in RT 011/RT04 Kampung Pisangan Poncol, Ragunan Village. 


\section{DISCUSSION}

From the results of the study, it was shown that the average level of knowledge on prevention of dengue hemorrhagic fever before giving health promotion through the video method was 6.84 and the average value of the level of knowledge after being given intervention through health promotion videos was 9.11 . This shows that after being given health promotion through the video method, they have increased knowledge about the prevention of dengue hemorrhagic fever. According to Notoatmodjo's theory (2010), knowledge is the result of information that is then noticed, understood, and remembered. Information can take various forms, both formal and informal education, such as reading newspapers, listening to the radio, watching TV. Knowledge is the result after people perceive that it occurs through the five senses, which are mostly obtained through the eyes and ears.

The results showed that the average value of attitudes towards preventing dengue hemorrhagic fever before giving health promotion through the video method was 49.61 and the average value of attitudes after being given an intervention through health promotion videos was 59.14. According to Sunaryo's theory (2004) attitude is the tendency of the response to act from the individual in the form of a closed response to a particular stimulus or object. Attitude is a feeling of supporting or sides (taking favorable) or feeling unsupportive (unfavorable) on an object. Based on the research, the practice frequency distribution shows that the average value of dengue hemorrhagic fever prevention practices before giving health promotion through the video method is 8.38 and the average practice after being given an intervention through health promotion videos is 11.05. According to Johnson (2012). Practice/action is a theory in understanding the actions that need to be taken to get the desired results in a situation. When the action has become a habit, then the action will always be carried out automatically.

The results showed that before (pre-test) the intervention was given the average level of knowledge was 23.46 and after (post-test) the intervention was given was 20.00 with a p-value of $0.000<0.05$. In line with the research conducted by Mia (2018) on "Health Education with the video and method on the leaflet Prevention of Dengue Hemorrhagic Fever in the Family of Dusun Rontega, West Nusa Tenggara", stated that health promotion or health education is able to influence public knowledge about the prevention of dengue hemorrhagic fever. with the video and method leaflet with the category if one is able to remember $20 \%$ of what is seen, $30 \%$ of what has been heard if someone is able to remember $50 \%$ of what is seen and heard, with a p-value of $0.001<a 0.005$. The results of the study also showed that before (pre-test) the intervention was given, the average attitude was 29.76 and after (post-test) the intervention was given it was 12.36 with a $p$-value of $0.000<0.05$.

These results are in line with Wantiyah et al (2016) regarding "The Effect of health Education Methods Brainstorming and Video on Knowledge and Attitudes About Dengue Fever in Families in the Work Area of the Jember District Health Center". Stating that the effect of health education with methods brainstorming and video. From the results of the study, it was also found that the average practice of preventing DHF before (pre-test) was given intervention was 26.93 and after (post-test) was 9.25 with a p-value of $0.000<0.05$. These results are in line with Hanna et al (2015) regarding "The Difference in Knowledge Improvement About Dengue Hemorrhagic Fever Between Lecture Methods And Animated Video In Class V and VI Students of SD Negeri 12 Metro Pusat", stating that differences in knowledge, attitudes, and practices about dengue fever dengue between lecture methods and animated videos in fifth and sixth-grade elementary school students, learning videos for starter and filling system materials are $75.58 \%$ while the lecture or conventional methods are $68.53 \%$ so it is found that animated videos have audio and visual elements simultaneously. so that it is easier to understand with the results of the statistical test $p=0.005$.

This is in accordance with Notoatmodjo's (2012) theory that health promotion is an activity to invite or provide and convey health information to the public, groups, or individuals. Health promotion is an effort made by the community so that they are willing and able to maintain and improve their own health. Health promotion media is a means to convey messages to the target so that it is easily understood by the target / intended party. In addition, health promotion media are all suggestions or efforts to display messages or information that communicators want to convey, both through print media, electronic mass media, and outdoor media so that the target can increase his knowledge which is ultimately expected to change his behavior towards positive about their health. Props or media have different intensities in helping someone's problems and in drawing the intensity of each teaching aid from the lowest to the highest (Maulana, 2009).

Video has the advantage of being able to describe the real situation or resemble the actual situation. Videos are dynamic so they are stimulating and easy to impress. Video also allows explanations to be repeated and can accelerate a person's level of understanding so that it can immediately change a person's attitude. Media in health promotion is one of the efforts to support the success of the learning process so that it attracts more attention and the material presented will be more easily understood by participants, through the video method it is easier to understand because it includes the two largest senses in communicating it (Haryani et al, 2015). This is in accordance with Budiharto (2012) that in the 
process of delivering health promotion materials to the target, the selection of the right method is very helpful for the speaker in an effort to change the behavior of the target.

\section{CONCLUSION}

In this study, it can be concluded that there is an increase in knowledge, attitudes, and practices towards dengue prevention in the community after being given health promotion through animated videos. Therefore, it is expected that every health worker is able to provide health promotion through various alternative health promotion media in order to increase and attract public attention in listening and studying the health promotion materials being taught.

\section{REFERENCES}

Guzman, et al, (2016). Demam Berdarah Dengue Cikungnya. Jurnal IImiah Universitas Airlangga. http://www.unair.ac.id accessed on 8 December 2020

Hasyim, D. M. (2013). Faktor-faktor Yang Berhubungan dengan Tindakan Pembernantasan sarang nyamuk Demam berdarh Dengue (PSN DBD ) Vol IV No 2 P 365. Rineka Cipta: Jakarta

Hidayat, A. A. (2011). Metode Penelitian Keperawatan \& Teknik Analisa Data. Salemba Medika: Jakarta.

Hanna, M., Aulia, S. P, \& Hanif, F. (2015). Perbedaan peningkatan penegetahuan, sikap, dan praktik tentang demam berdarah dengue anatara metode ceramah dan video animasi pada murid kelas V Sd Negeri Metro pusat.

Jhonson, D. W., \& Jhonson, F. P. (2012). Dinamika kelompok teori dan ketrampilan. Edisi kesembilan. PT. Indeks: Jakarta.

Kemenkes R. I. (2020). Riset Kesehatan Dasar, Badan Penelitian dan Pengembangan Kesehatan. Kementerian Kesehatan Republik Indonesia: Jakarta.

Kemenkes RI. (2018). Situasi Penyakit Demam Berdarah di Indonesia Tahun 2017. Pusat Data dan Informasi Kementrian Kesehatan Rl: Jakarta

Notoatmodjo, S. (2012). Tujuan dan strategi Promosi Kesehatan. Airlangga University Press: Surabaya.

Notoatmodjo, S. (2014). Metodelogi Penelitian Kesehatan. Rineka Cipta: Jakarta. http://www.lib.unnes.ac.id accessed on 29 January 2021

Pooja, C., Yadav A., \& Chawla, V. (2014). Clinical Implications and Treatment of Dengue. Asian Pacific Journal of Tropical Medicine, 169-178.

Pratiwi, A. (2016). Perbedaan peningkatan pengetahuan tentang Demam berdarah Dengue (DBD) antara metode ceramah dan video animasi Pada Masyarakat (htpp://juke.kedokteran.unila.ac.id/index.php/majority/article/view/2050/) accessed on 14 October 2020

Profil Kesehatan. (2020). Angka Kesakitan Demam Berdarah Dengue (DBD) 2020. Dinas Kesehatan Jakarta Selatan

Sugiono. (2014). Statistik untuk penelitian. Alfa Beta: Bandung.http://www.unsri.ac.id, accessed on 8 August 2020 